\title{
SUBSTITUTION OF FISH OIL WITH PALM KERNEL OIL IN DIETS OF Oreochromis niloticus FRY: EFFECTS ON GROWTH, FEED UTILIZATION AND ECONOMIC ESTIMATES
}

\author{
Christian Larbi Ayisi*\#, Elliot Haruna Alhassan*, and Freda Sarfo ${ }^{* *}$ \\ "Department of Water Resources and Sustainable Development, School of Sustainable Development, University of \\ Environment and Sustainable Development \\ Somanya, Eastern Region, Ghana \\ *) Department of Fisheries and Aquatic Resources Management, Faculty of Biosciences, \\ University for Development Studies, Tamale, Ghana
}

(Received: March 9, 2021; Final revision: May 25, 2021; Accepted: May 25, 2021)

\begin{abstract}
This study assessed the impact of replacing fish oil with palm kernel oil (PKO) in the diets of Oreochromis niloticus fry on growth, feed efficiency and proximate composition. Three isonitrogenous ( $30 \%$ crude protein) and isolipidic ( $10 \%$ crude lipid) diets were formulated using palm kernel oil as a substitute for fish oil at 0\%(PKO-0), 50\%(PKO-50), and 100\% (PKO-100). Two hundred 0. niloticus fry with initial weight of $0.80 \pm 0.25 \mathrm{~g}$ were purchased from Water Research Institute Upper West, Ghana and transported to the Spanish Laboratory of University for Development Studies (Ghana) where they were kept and fed two times a day on commercial diet from Ranaan feed for two weeks. The fry was then stocked in triplicate groups in $60 \mathrm{~L}$ tanks $(50 \mathrm{~cm} \times 40 \mathrm{~cm} \times 40 \mathrm{~cm})$ at 20 fry per tank. At the end of the eight weeks feeding trial, there was a significant difference amongst the three treatments with respect to final weight, weight gain, feed conversion ratio, and specific growth rate. It was observed that the least mean values for feed intake, protein productive value, protein efficiency ratio, and protein intake occurred in fish fed PKO-0. There was a trend of increasing whole body moisture content as palm kernel oil increased. Fish fed PKO-0 recorded the lowest lipid content $(7.48 \pm 1.13 \%$ in the whole body. From the economic analysis, it is evident that palm kernel oil is a cheaper source of lipid for tilapia. This study therefore recommends palm kernel oil as a substitute for tilapia diet.
\end{abstract}

\section{KEYWORDS: palm kernel oil; economic analysis; growth; tilapia; fish oil}

\section{INTRODUCTION}

Lipids serve as the main source of fatty acids as well as energy in higher trophic organisms and their roles cannot be substituted by other nutrients (Wang et al., 2013). The major lipid source in aquafeed is fish oil (Leaver et al., 2008). This is because it serves as an excellent source of long chain polyunsaturated fatty acids, LC-PUFA (Sargent et al., 2002). As a result of increase in demand coupled with decline in production and higher prices of fish oil, there is the need for other suitable lipid sources to be explored (FAO, 2016).

It has been reported that vegetable oils (VOs) are suitable and can be used as potential candidates to

\# Correspondence: Department of Water Resources and Sustainable Development, School of Sustainable Development, University of Environment and Sustainable Development. Somanya, Eastern Region, Ghana

E-mail: aclarbi@ uesd.edu.gh replace fish oils in aquafeeds (Lin \& Shiau, 2007). Compared to fish oil, VOs are cheap, and have low organic contaminants, higher amounts of unsaturated fatty acids and high accessibility (Ayisi et al., 2018).

VOs possess higher quantities of $\mathrm{C} 18$ monounsaturated FA (MUFA) and C18 PUFA such as linoleic acid (LA, 18:2n6) and a-linolenic acid (ALA, $18: 3 n 3)$, but deficient in eicosapentaenoic acid (EPA, 20:5n3), docosahexaenoic acid (DHA, 22:6n3) and arachidonic acid (ARA). These deficient fatty acids are essential to human health and must therefore be present in the fillets of the fish (Piedecausa et al., 2007). Palm oil, soybean oil, canola oil, sunflower oil as well as palm kernel oil are some plant based oils with potential of being used as lipid sources in fish feed.

About a quarter of oils and fats supplied worldwide are accounted for by palm kernel oil. This there- 
fore makes it the largest edible oil traded worldwide. Palm kernel oil is gotten from the kernel of palm nut; the oil is distinct from palm oil in terms of its fatty acid composition, and level of saturation. Palm kernel oil, which is semi-solid at room temperature, is more saturated than palm oil and compared to coconut oil. About $81 \%$ of the fats in palm kernel oil are saturated while only $41 \%$ in palm oil are saturated (Harold, 2004). Hence, palm kernel oil, being a cheap source of lipids with the necessary qualities to support optimum growth of fish was adopted for this experiment to be included in the diet for tilapia.

There is scanty information available on the effects of replacing fish oil with palm kernel oil on growth performance, feed utilization, proximate, and fatty acid composition with respect to Nile tilapia. There are however some studies on Catfish (Ayuba et al., 2015) and hybrid grouper juvenile (Epinephelus fuscoguttatus x Epinephelus lanceolatus) (Yong et al., 2019) which reported that substituting fish oil with palm kernel oil to a large extent can enhance growth.

Tilapia is the most common freshwater cichlids which are of commercial interest and are mostly exploited as food. The nile tilapia (Oreochromis niloticus) is a deep-bodied fish with cycloid scales which often flushes red during the breeding season (Picker \& Griffiths, 2011). It has been reported by (FAO, 2012) that nile tilapia grows to a maximum length of $62 \mathrm{~cm}$, weighing $3.65 \mathrm{~kg}$ (at an estimated nine years of age). The average length (total length) of 0 . niloticus is $20 \mathrm{~cm}$ (Bwanika et al., 2004). The objective of the study was to evaluate the effects of replacing fish oil with palm kernel oil on growth performance, feed utilization, proximate composition, and economic analysis of production.

\section{MATERIALS AND METHODS}

\section{Diets and Feeding Trials}

Three diets with similar protein (crude protein, $30.33 \%$ and lipid (crude lipid, $10.66 \%$ were formulated for this study. The diets were prepared following methods employed by Ayisi et al. (2017). The progressive enlargement method was used by mixing the dry ingredients (fish meal, soybean meal, wheat bran, vitamins, minerals, salt, and starch) first. Fish oil, palm kernel oil and water were subsequently added to the pre-mix dry ingredients. Meat mincer with $1 \mathrm{~mm}$ diameter was used to pelletize the feed, sun dried, broken into smaller pieces, and stored at room temperature. The diets were designated the following abbreviations; PKO-0, PKO-50, and PKO-100 to depict the inclusion levels of palm kernel oil. Diet PKO-0 had 6\% fish oil and 0\% palm kernel oil with diets PKO-50 and PKO-100 containing 3\%fish oil and
$3 \%$ palm kernel oil as well as $0 \%$ fish oil and $6 \%$ palm kernel oil respectively. Table 1 and 2 shows the ingredients and proximate composition of the three experimental diets respectively.

Table 1. Feed formulation and feed ingredients $(\%)$

\begin{tabular}{lccc}
\hline \multirow{2}{*}{ Ingredients } & \multicolumn{3}{c}{ PKO } \\
\cline { 2 - 4 } & $\mathbf{0}$ & $\mathbf{5 0}$ & $\mathbf{1 0 0}$ \\
\hline Fish meal & 10.00 & 10.00 & 10.00 \\
Soybean meal & 38.00 & 38.00 & 38.00 \\
Wheat bran & 40.00 & 40.00 & 40.00 \\
Fish oil & 6.00 & 3.00 & 0.00 \\
Palm kernel oil & 0.00 & 3.00 & 6.00 \\
Vitamin premix & 1.00 & 1.00 & 1.00 \\
Mineral premix & 1.00 & 1.00 & 1.00 \\
Starch & 3.00 & 3.00 & 3.00 \\
Salt & 1.00 & 1.00 & 1.00 \\
\hline Total & $\mathbf{1 0 0 . 0 0}$ & $\mathbf{1 0 0 . 0 0}$ & $\mathbf{1 0 0 . 0 0}$ \\
\hline
\end{tabular}

Table 2. Proximate composition of fish feed

\begin{tabular}{lccc}
\hline \multirow{2}{*}{$\begin{array}{c}\text { Proximate } \\
\text { analysis }\end{array}$} & \multicolumn{3}{c}{ PKO } \\
\cline { 2 - 4 } & $\mathbf{0}$ & $\mathbf{5 0}$ & $\mathbf{1 0 0}$ \\
\hline Protein (\%DM) & 30.77 & 30.85 & 30.25 \\
Lipid (\%DM) & 10.45 & 10.72 & 10.82 \\
Dry matter (\%DM) & 85.65 & 85.65 & 85.65 \\
Ash (\%DM) & 4.86 & 4.86 & 4.86 \\
\hline
\end{tabular}

\section{Fish and Husbandry}

Two hundred nile tilapia fry was purchased from Water Research Institute, Wa, Ghana and transported to the Spanish Laboratory of University for Development Studies, Tamale, Ghana. The fish was stocked in two 60-L tanks and fed a commercial diet purchased from Ranaan feed twice daily for two weeks to adapt them to the experimental facilities and conditions.

The experiment was conducted in triplicates with fish stocked at 20 fish per tank (60-L) and fish fed their respective diets to apparent satiation two times a day (08:30 and 17:00 pm) for eight weeks.

\section{Sampling}

Feeding was stopped twenty-four hours before sampling. This ensured that the stomach is empty and also to reduce stress during sampling. The weight $(\mathrm{g})$ and length $(\mathrm{cm})$ of the fish that survived were measured. Also, the total number of fish in each tank was counted. Five fish per tank were sampled and stored in a fridge at $-20^{\circ} \mathrm{C}$. 


\section{Growth and Feed Utilization}

The objective of the study was to evaluate the effects of the diets on growth and feed efficiency by nile tilapia, the following equations were used to measure the above mentioned parameters.

Weight gain (WG) = Final weight $(\mathrm{g})$ - Initial weight $(\mathrm{g})$

$$
\operatorname{SGR}(\% \text { day })=\frac{(\ln F W(g)-\ln \operatorname{IW}(g))}{T} \times 100
$$

Where: $T$ is the number of experimental (feeding) days $\mathrm{SGR}=$ Specific growth rate

$$
\text { Condition factor }(K)=\left[\frac{\text { body weight }}{\text { total length }}{ }^{3}\right] \times 100 \%
$$

Total length is in $\mathrm{cm}$

Feed intake (FI) is the total feed consumed $(\mathrm{g})$ per fish during the 56 days' trial

Feed convertion ratio $(\mathrm{FCR})=\frac{\text { feed intake }(\mathrm{g})}{\text { weight gain }(\mathrm{g})}$

Protein efficiency ratio $(P E R)=\frac{\text { wet weight gain }(g)}{\text { protein intake }(g)}$

Hepatosomatic index $(\mathrm{HSI})=100 \times \frac{\text { (liver weight) }}{\text { (body weight) }}$

Protein intake $(\mathrm{PI})=$ protein content of feed $\mathrm{x}$ feed intake

Protein productive value $(\mathrm{PPV})=\frac{\text { protein gain }(\mathrm{g})}{\text { protein intake }(\mathrm{g})}$

$$
\text { WG }(\%)=100 \frac{\text { [final weight }(\mathrm{g}) \text { - initial weight }(\mathrm{g}) \text { ] }}{\text { initial weight }}
$$

\section{Proximate Composition}

Samples of experimental diets and fish (five fishes per tank) were sent to the Spanish Laboratory of University for Development Studies, Nyankpala Campus for analysis of moisture, ash, lipids, and protein. The standard methods of AOAC (2003) as described by Mehbood et al. (2017) were used in analysing the parameters above.

\section{Economic Estimates}

The economic conversion ratio (ECR) was calculated as previously used by Piedecausa et al. (2007). The calculations were based on the prices of the raw materials $(\mathrm{GH} \phi)$ used to formulate each diet. This is basically the cost involved in producing a $\mathrm{kg}$ of each diet. The raw material prices during the experimental period, due to the fact that there may be significant changes throughout the year. The economic conversion ratio (ECR) will be determined using the following equation; ECR - (Cost of diet $x$ feed conversion ratio).

\section{Statistical Analysis}

Data obtained was statistically analysed using Graph Pad Prism (V.5.03). The data is presented in graphs and tables using the mean \pm standard error of the mean (SEM ). One-way Analysis of Variance and Tukey's multiple tests was used to analyse all data to compare treatment means. Differences are considered significant at 0.05 probability level $(P<0.05)$ for all data.

\section{RESULTS AND DISCUSSION}

\section{Growth Performance and Survival}

Due to the high cost of fish oil which is a main component of fish feed (Shiau \& Lin, 1993; Apraku et al., 2017), there are calls for alternatives to be used. Based on this, several studies have been conducted to evaluate the effect of dietary VOs on growth performance and feed utilization (Aziza et al., 2013; Keremah \& Terimokumo, 2014; Choi \& Lee, 2015). Some of these studies have shown the effects of dietary vegetable oil source on growth performance, feed utilization, proximate composition, and fatty acid composition of rainbow trout (Betiku et al., 2016; Bullerwell et al., 2016). But this current work is the first study evaluating the effect of dietary palm kernel oil on growth performance, feed utilization, and proximate composition in 0 . niloticus.

Table 3 shows growth performance of the three experimental groups. Final weight of nile tilapia fed PKO-0 was significantly lower than that of fish fed with PKO-100\% (PKO-100) $(P<0.05)$. Weight gain of nile tilapia fed with the three experimental diets was significantly different among treatments. Fish fed PKO-0 recorded the least weight gain $(7.04 \pm 0.049$ g) and was significantly lower than fish fed PKO-50 $(8.21 \pm 0.030 \mathrm{~g})$ and PKO $-100(8.47 \pm 0.09 \mathrm{~g})(P<0.05)$. The specific growth rate (SGR) recorded in this study ranged between $3.94 \%$ and $4.23 \%$ There was a trend of increasing SGR with increasing PKO levels. Fish fed higher levels of palm kernel oil (PKO-50 and PKO-100) recorded significantly higher SGR values compared to the group fed PKO-0 $(P<0.05)$. Survival was $100 \%$ for all groups. 
Table 3. Growth parameters of nile tilapia (0. niloticus) fed with different levels of palm kernel oil

\begin{tabular}{lcccc}
\hline \multirow{2}{*}{ Growth parameters } & \multicolumn{3}{c}{ PKO } & \multirow{2}{*}{ p-value } \\
\cline { 2 - 4 } & $\mathbf{0}$ & $\mathbf{5 0}$ & $\mathbf{1 0 0}$ & \\
\hline Initial body length (cm) & $1.33 \pm 0.06$ & $1.35 \pm 0.08$ & $1.31 \pm 0.05$ & 0.9167 \\
Initial body weight (g) & $0.87 \pm 0.05$ & $0.85 \pm 0.04$ & $0.87 \pm 0.03$ & 0.9483 \\
Final weight (g) & $7.91 \pm 0.31^{\mathrm{a}}$ & $9.07 \pm 0.20^{\mathrm{b}}$ & $9.34 \pm 0.41^{\mathrm{b}}$ & 0.0100 \\
Weight gain (g) & $7.04 \pm 0.03^{\mathrm{a}}$ & $8.21 \pm 0.02^{\mathrm{b}}$ & $8.47 \pm 0.07^{\mathrm{b}}$ & 0.0004 \\
Percentage weight gain (\%) & $809.5 \pm 13.50^{\mathrm{a}}$ & $961.0 \pm 8.00^{\mathrm{b}}$ & $968.5 \pm 2.50^{\mathrm{b}}$ & 0.0019 \\
Specific growth rate (\%day) & $3.94 \pm 0.01^{\mathrm{a}}$ & $4.25 \pm 0.01^{\mathrm{b}}$ & $4.23 \pm 0.05^{\mathrm{b}}$ & 0.0008 \\
Survival (\%) & 100 & 100 & 100 & --- \\
\hline
\end{tabular}

Note: $\quad$ All values are mean \pm SEM. Different superscript in each row represents significant differences $(p<0.05)$ determined by one way ANOVA

The present study shows that increasing palm kernel oil in diets of 0 . niloticus affected the final body weight, weight gain, and specific growth rate of 0 . niloticus significantly. The result of the present study reveals that palm kernel oil can be used to replace fish oil and have positive effect on 0 . niloticus growth as reported for other fish species (Turchini et al., 2003; Francis et al., 2006; Ochang et al., 2007). There was an increase in growth performance (final weight, weight gain, and SGR) which indicates that feeding $O$. niloticus with dietary palm kernel oil does not affect growth negatively. This might be attributed to PKO being able to meet the energy requirement of fish by providing fatty acids that are oxidized easily (Babalola et al., 2011). The better growth as recorded in the PKO diets could be due to a balance in $n-3$ and $n-6$ fatty acids which are needed for improving growth even though this study did not analyse fatty acids. In addition, freshwater fishes such as tilapia and catfish have preference for $n-6$ fatty acids which are dominant in VOs compared to n-3 fatty acids which are dominant in fish oil (Ochang et al., 2007). Growth performance reported in this study is in contrast to a study by Babalola \& Apata (2012) which reported that substituting fish oil with palm oil do not compromise growth. Similarly, Keremah \& Terimokumo (2014) documented that feeding mudfish (Heterobranchus longifilis) with palm oil and soybean oil instead of cod liver oil led to an increase in growth performance.

\section{Feed Utilization, Condition Factor, and Hepasomatic Index}

Table 4 gives a summary of feed utilization, condition factor as well as hepatosomatic index. The three experimental diets had no significant influence on hepasomatic index $(p>0.05)$. It is however impor- tant to note that fish fed PKO-100 recorded the highest HSI value of $1.39 \pm 0.04$. Substituting fish oil with palm kernel oil significantly affected condition factor $(p<0.05)$. The least condition factor $(1.51 \pm 0.01)$ was recorded in fish fed PKO-50, this was followed by fish fed PKO - 100 and PKO-0 with mean condition factor values of $1.76 \pm 0.00$ and $1.85 \pm 0.02$ respectively.

There was significant difference in protein intake among the three groups. The mean protein efficiency ratio ranges from 2.42 to 2.80 . The result shows that protein intake was significantly influenced by the three experimental diets $(p<0.05)$. Comparatively, fish fed PKO-50 and PKO-100 had a higher protein intake than fish fed PKO-0. Protein intake value ranges between $3.33 \pm 0.00$ and $3.46 \pm 0.02$. Protein productive value (PPV) recorded after the eight (8) weeks feeding trial. PPV values recorded in fish fed PKO100 was not significantly higher than fish fed PKO50 , but significantly higher than fish fed PKO-0.

This study showed a trend of decreasing feed conversion ratio as palm kernel oil increased in the experimental diet. Compared to the control diet (PKO$0)$, FCR in fish fed PKO-50 decreased by 0.13 whilst FCR of fish fed PKO-100 decreased by 0.2. There was significant difference among the three treatments $(p<0.05)$. Feed conversion ratio of fish fed PKO -0 was significantly higher than both PKO-50 and PKO-100.

The decrease in feed conversion ratio (FCR) as palm kernel oil increased in this study indicates that the various treatments had different abilities with respect to digestion and conversion of the experimental diets to muscle. Yong et al. (2019) replaced fish oil with crude palm kernel oil and reported FCR of 1.26 and 1.47 for FO and crude palm kernel oil (CPKO), respectively. This indicates that feeding hy- 
Table 4. Feed utilization and efficiency of 0 . niloticus with different levels of palm kernel oil

\begin{tabular}{lcccc}
\hline \multirow{2}{*}{ Parameters } & \multicolumn{3}{c}{ Dietary PKO inclusion level } & \multirow{2}{*}{ p-value } \\
\cline { 2 - 4 } & PKO-0 & PKO-50 & PKO-100 & \\
\hline Feed conversion ratio & $1.54 \pm 0.01^{\mathrm{c}}$ & $1.37 \pm 0.03^{\mathrm{b}}$ & $1.30 \pm 0.11^{\mathrm{a}}$ & 0.0004 \\
Protein efficiency ratio & $2.42 \pm 0.04^{\mathrm{a}}$ & $2.76 \pm 0.20^{\mathrm{b}}$ & $2.80 \pm 0.01^{\mathrm{b}}$ & 0.0049 \\
Hepatosomatic index & $1.369 \pm 0.04$ & $1.363 \pm 0.02$ & $1.396 \pm 0.03$ & 0.7839 \\
Condition factor & $1.85 \pm 0.01^{\mathrm{c}}$ & $1.51 \pm 0.01^{\mathrm{a}}$ & $1.76 \pm 0.00^{\mathrm{b}}$ & 0.0007 \\
Protein productive value (PPV) & $8.64 \pm 0.07^{\mathrm{a}}$ & $9.00 \pm 0.01^{\mathrm{b}}$ & $9.11 \pm 0.06^{\mathrm{b}}$ & 0.0185 \\
Feed intake (g/fish) & $10.83 \pm 0.37$ & $11.27 \pm 0.33$ & $11.06 \pm 0.38$ & 0.6886 \\
\hline
\end{tabular}

Note: All values are mean \pm SEM. Different superscript in each row represents significant differences $(p<0.05)$ determined by one way ANOVA

brid grouper juvenile with FO was better than CPKO. This is however contrary to our result. This is because grouper is a marine fish which has less preference for VOs.

The significant difference observed in PER in this study is contrary to the previous results which obtained no significant difference in PER when fish oil was replaced with other VOs in diets of gilthead sea bream (Wassef et al., 2009) and chinook salmon parr, Oncorhynchus tshawytscha (Huang et al., 2008). Fish fed diet PKO-50 had the highest feed intake. This study is in agreement with study by Baoshan et al. (2019) which reported significant difference in feed intake when fish oil was replaced with wheat germ oil in diets of juvenile hybrid grouper. On the contrary, Toyes-Vargas et al. (2020) reported a nonsignificant reduction in feed intake when substituted fish oil with camelina oil in diets of juvenile tilapia. In addition, Mu et al. (2020) reported no significant diffe-rence in feed intake when fish oil diets of large yellow croaker (Larimichthys crocea) were substituted with rapeseed oil. There was a reduction in feed intake when fish oil was replaced with more than $50 \%$ PKO. This could be associated with a decrease in feed intake which may be due to feed intake depression.

Condition factor is used to measure the relationship between the length and weight of fish. This index is a good measure of the health of the fish. Contrary to this present study, Ayisi et al. (2018) and Apraku et al. (2017) observed non-significant difference in condition factor when fish oil was replaced with VOs in Nile tilapia. Also, Lazzari et al. (2016) observed no significant difference in silver catfish (Rhamdia quelen) fed diets with soybean oil. There was however, significant difference in condition factor in previous report by Güler \& Yildiz (2011) and is in agreement with this present study. The differences observed in these studies could be as a result of differences in levels of lipids and fish species studied (Masiha et al., 2013).
The non-significant difference observed in hepatosomatic index (HSI) of this study confirms an earlier report by Anvo et al. (2017). In their report feeding catfish with cashew kernel oil instead of fish oil did not affect HSI significantly. Similarly, there was no significant difference in previous studies in other fish species such as European sea bass (Mourente et al., 2005), Darkbarbel catfish (Jiang et al., 2013). The liver is the main site for lipid deposition (Corraze, 1999). The non-significant difference reported in this study reveals that lipid was deposited in the liver at relatively the same concentration (Anvo et al., 2017). However, Sener \& Yildiz (2003) found that the hepatosomatic index value computed from rainbow trout juvenile feed containing fish oil was significantly lower than the fish fed diets containing VOs (soya bean and sunflower). Feeding catfish with diets containing soybean oil showed higher HSI than those fed fish oil (Babalola et al., 2011). These differences could be attributed to difference in lipid content, size or age of fish as well as differences in species. Also, $\mathrm{HSI}$ values isvary as a function of dietary carbohydrates and protein (Richard et al., 2006).

\section{Proximate Composition (Whole Body)}

Table 5 shows proximate composition (whole body) of the three experimental groups of fish. With exception of protein there was no significant difference in moisture, lipid, and ash contents of the whole body of fish ( $p>0.05)$. Moisture, protein, lipid, and ash contents of the whole body ranged from $71.01 \%$ $71.84 \%$ 59.59\%62.78\% $7.48 \% 8.58 \%$ and $3.96 \% 4.20 \%$ respectively.

Evaluation of fish quality which involves a comprehensive assessment of the sensory characteristics, physical and chemical properties, nutritional value, and food safety of fresh or processed meat is a complex process (Hofmann, 1994). Protein, lipid, and carbohydrates are the basic parameters used to evaluate the nutritional fish quality. Several studies have 
Table 5. Proximate composition of fish fed diets with elevated palm kernel oil levels

\begin{tabular}{lcccc}
\hline \multirow{2}{*}{ Parameters } & \multicolumn{3}{c}{ Dietary PKO inclusion level } & \multirow{2}{*}{ p-value } \\
\cline { 2 - 4 } & PKO-0 & PKO-50 & PKO-100 & \\
\hline Moisture (\%) & $71.01 \pm 0.34$ & $71.61 \pm 0.26$ & $71.84 \pm 2.61$ & 0.8596 \\
Protein (\%DM) & $59.59 \pm 0.26^{\text {a }}$ & $62.21 \pm 0.11^{\mathrm{b}}$ & $62.78 \pm 0.04^{\mathrm{b}}$ & 0.0043 \\
Lipid (\%DM) & $7.48 \pm 1.31$ & $8.24 \pm 0.38$ & $8.58 \pm 0.10$ & 0.4628 \\
Ash (\%DM) & $3.96 \pm 0.3$ & $4.20 \pm 0.2$ & $3.98 \pm 0.4$ & 0.3203 \\
\hline
\end{tabular}

reported on the influence of replacing fish oil with VOs on proximate or biochemical composition of fish (Babalola \& Apata, 2012; Aziza et al., 2013; Ayisi et al., 2017). Substituting fish oil with palm kernel oil did not alter moisture and lipid content in the whole body of 0 . niloticus. Protein levels however, increased significantly as palm kernel oil content increased in the experimental diets. Ackman (1990) classified fish into three based on their fat content, i.e. fish with fat content of $<4 \%$ as low fat fish whilst those with fat content of $4 \% 8 \%$ and $>8 \%$ were classified as medium and high fat fish. From this study, fish fed diets with $0 \%$ PKO can be classified as medium fat fish whilst those fed PKO 50\%and PKO 100\%can be classified as high fat fish. There was no significant difference in moisture and protein content when fish oil was substituted by palm oil and cashew kernel oil in diets of catfish (Anvo et al., 2017). On the other hand, Yildiz et al. (2013) documented that feeding Rainbow trout, Oncorhynchus mykiss cotton seed and/or canola oil in place of fish oil led to a significant difference in moisture, crude protein, and lipid content of the whole body. The different results in lipid content reported in this present study with that of previous studies (Yildiz et al., 2013; Anvo et al., 2017) could be attributed to different sources of lipids since it has been reported that the lipid content of fish tissues could be significantly altered by the dietary lipid from different source (Sargent et al., 2002). In addition, not only nutritional factors but endogenous and exogenous factors affect biochemical or proximate composition of fish (Aziza et al., 2013).

\section{Economic Analysis}

The economic analysis of the three experimental diets is shown in Table 6 . The cost of producing a kilogram of PKO-0, PKO-50, and PKO-100 were GH $\&$ 1.37, $\mathrm{GH} \nsubseteq 3.46$, and $\mathrm{GH} \nsubseteq 4.3$, respectively. There was significant difference in the economic conversion ratio (ECR) of the three experimental diets $(\mathrm{P}<0.05)$. Groups fed PKO-0, PKO-50, and PKO-100 recorded an ECR of $6.62,5.35$, and 4.49 , respectively. The reduction in economic conversion ratio as well as increase in cost reduction implies substitution of fish oil with palm kernel oil is economically prudent.

\section{CONCLUSIONS}

In conclusion, this study documents that substitution of fish oil with palm kernel oil improves growth and feed utilization in nile tilapia, and also effective to reduce cost of feed. This study recommends that fish oil in diets of nile tilapia could be completely replaced by palm kernel oil without negative effects on growth and feed utilization.

\section{STATEMENT OF CONFLICT OF INTEREST}

Authors have declared no conflict of interest.

\section{REFERENCES}

Ackman, R.G. (1990). Seafood lipids and fatty acids. Food Reviews International, 6, 617-646.

Anvo,M.P.M., Sissao, R., Aboua, B.R.D., ZoungranaKaboré, C.Y., Otchoumou, A.K., Kouamelan, E.P., $\&$ Toguyéni, A. (2017). Preliminary use of cashew

Table 6. Cost of producing a $\mathrm{kg}$ feed, economic conversion ratio, and cost reduction/ $\mathrm{kg}$ of fish fed the experimental diets

\begin{tabular}{lccc}
\hline \multirow{2}{*}{ Parameters } & \multicolumn{3}{c}{ PKO } \\
\cline { 2 - 4 } & $\mathbf{0}$ & $\mathbf{5 0}$ & $\mathbf{1 0 0}$ \\
\hline Cost of producing a kg feed $(\mathrm{GH} \mathbb{\mathbb { C }})$ & 4.30 & 3,46 & 1,37 \\
ECR* & $6.62 \pm 0.06$ & $4.74 \pm 0.07$ & $1.78 \pm 0.06$ \\
Cost reduction $/ \mathrm{kg}^{* *}(\mathrm{GH} \mathbb{C})$ & 0 & $1.88 \pm 0.05$ & $4.84 \pm 0.04$ \\
\hline
\end{tabular}

Note: *ECR: Economic conversion ratio; **Cost reduction $/ \mathrm{kg}$ 
kernel oil inClarias gariepinus fingerlings diet: Comparison with fish oil and palm oil. Int. Aquat. Res., 9,129-139.

AOAC. (2003). Official methods of analysis, 17th ed. Association of Official Analytical Chemists, Washington D.C., USA.

Apraku, A., Liu, L., Leng, X., Rupia, E.J., \& Ayisi, C.L. (2017). Evaluation of blended virgin coconut oil and fish oil on growth performance and resistance toStreptococcus iniae challenge of nile tilapia (Oreochromis niloticus). Egypt. J. Basic Appl. Sci., 4(3), 175-84.

Ayisi, C.L. \& Zhao, J.L. (2017). Fatty acid composition, lipogenic enzyme activities and MRNA expression of genes involved in the lipid metabolism of nile tilapia fed with palm oil. Turkish Journal of Fisheries and Aquatic Sciences, 17, 405415.

Ayisi, C.L., Zhao, J., \& Wu, J.W. (2018). Replacement of fish oil with palm oil: Effects on growth performance, innate immune response, antioxidant capacity and disease resistance in nile tilapia (Oreochromis niloticus). PLoS ONE, 13(4):e0196100.https://doi.org/10.1371/ journal.pone.0196100.

Ayuba, V.O., Alli, M.A., \& Oyeniyi, M.E. (2015). Effects of fish oil replacement with palm kernel oil as lipid source on the growth performance of Clarias gariepinus fingerlings. Direct Research Journal of Agriculture and Food Science, 3(6),132-137.

Aziza, A.E., Awadin, W.F., \& Orma A.M. (2013). Effect of dietary substitution of codliver oil by VOs on growth performance, body composition, lipid peroxidation, liver and muscle histopathological state in nile tilapia (Oreochromis niloticus). Journal of Fisheries and Aquaculture, 4(2), 87-94.

Babalola, T.O., Apata, D.F., Omotosho, J.S., \& Adebayo, M.A. (2011). Differential effects of dietary lipids on growth performance, digestibility, fatty acid composition and histology of African catfish (Heterobranchus longifilis) fingerlings. Food and Nutrition Sciences, 2,11-21.

Babalola,T.0. \& Apata, F. (2012). Effects of dietary lipid source on growth, digestibility and tissue fatty acid composition of Heterobranchus longifilis fingerlings. Rural Development in the Tropics and Subtropics,113(1), 1-11.

Baoshan, L., Jiying, W., Yu, H., Tiantian, H., Shixin, W., BingShan, H., \& Yongzhi, S. (2019). Effects of replacing fish oil with wheat germ oil on growth, fat deposition, serum biochemical indices and lipid metabolic enzyme of juvenile hybrid grouper (Epinephelus fuscoguttatus $f \times$ Epinephelus lanceolatus m). Aquaculture, 505, 54-62. doi:10.1016/j.aquaculture.2019.02.037.

Betiku, O.C., Barrows, F.T., Ross, C., \& Sealey, W.M. (2016). The effect of total replacement of fish oil with DHA-Gold ${ }^{\circledR}$ and plant oils on growth and fillet quality of rainbow trout (Oncorhynchus mykiss) fed a plant-based diet. Aquaculture Nutrition, 22, 158-169.

Bullerwell, C.N., Collins, S.A., Lall, S.P., \& Anderson, D.M. (2016). Growth performance, proximate and histological analysis of rainbow trout fed diets containing Camelinasativa seeds meal (high-oil and solvent extracted) and oil. Aquaculture, 452, 342350. DOI:10.1016/j.aquaculture.2015.11.008.

Bwanika, G.N., Makanga, B., Kizito, Y., Chapman, L.J., $\&$ Balirwa, J. (2004). Observations on the biology of nile tilapia, Oreochromis niloticus,L., in two Ugandan Crater lakes. African Journal of Ecology, 42, 93-101.

Choi, J. \& Lee, S.M. (2015). Effect of dietary lipid sources on body fatty acid composition of Chinese long snout catfish Leiocassis longirostris Günther. Fish Aquat.Sci., 18, 359-65.

Corraze, G. (1999). Nutrition lipidique. In: Guillaume, J., Me'tailler, R., Bergot, P., Kaushik, S.J. (Eds.). Nutrition des poissonset des crustace's. Paris: Inrae' ditions.

Food and Agriculture Organization [FAO]. (2016). The state of world fisheries and aquaculture 2016: Contributing to food security and nutrition for all. Rome, Italy: FAO of the United Nations.

Food and Agriculture Organization [FAO].(2012). Fisheries global information system.FAO Fisheries and Aquaculture. Department, Food and Agriculture Organization of the United Nations, Rome.

Francis, D.S., Turchini, G.M., Jones, P.L., \& Silva, S.S.D. (2006). Effects of dietary oil source on growth and fillet fatty acid composition of Murray cod, Maccullochella peelii peelii. Aquaculture, 253, 547556.

Güler, M. \& Yildiz, M. (2011). Effects of dietary fish oil replacement by cottonseed oil on growth performance and fatty acid composition of rainbow trout (Oncorhynchus mykiss). Turkish Journal of Veterinary and Animal Sciences, 35(2), 157-167.

Harold, M. (2004). On food and cooking: The science and love of the kitchen. Scribner. ISBN: 978-0-68480001-1. 
Hofmann, K. (1994). What is quality? Definition, measurement and evaluation of meat quality. Meat Focus International, 19(7), 43-51.

Huang, S.S.Y., Fu, C.H.L., Higgs, D.A., Balfry, S.K., Schulte, P.M., \& Brauner, C.J. (2008). Effects of dietary canola oil level on growth performance, fatty acid composition and ionoregulatory development of spring chinook salmon parr, Oncorhynchus tshawytscha. Aquaculture, 274, 109-117.

Jiang, X., Chen, L., Qin, J., Qin, C., Jiang, H., \& Li, E. (2013). Effects of dietary soybean oil inclusion to replace fish oil on growth, muscle fatty acid composition, and immune responses of juvenile darkbarbel catfish, Pelteobagrus vachelli. Afr. J. Agric. Res., 8, 1492-1499.

Keremah, R.I. \& Terimokumo, T. (2014). Effects of dietary lipid sources on growth and survival of mudfish Heterobranchus longifilis fingerlings. Journal of Applied Biology \& Biotechnology, 2(01), 009-012.

Lazzari, R., Emanuelli, T., Maschio, D., Ferreira, C.C., Battisti, E.K., \& Radünz-Neto, J. (2016).The inclusion of soybean oil in the diets of silver catfish (Rhamdia quelen) in relation to growth quality and fillet acceptability. Lat. Am. J. Aquat. Res., 44(1), 39-45.

Leaver, M.J., Bautista, J.M., Bjornsson, B.T., Onsson, E.J., Krey, G., \& Tocher, D.R. (2008). Towards fish lipid nutrigenomics: Current state and prospects for fin-fish aquaculture. Rev. Fish. Sci., 16,73-94.

Lin, Y.H. \& Shaiu, S.Y. (2007). Effects of dietary blend of fish oil with corn oil on growth and non-specific immune response of grouper, Epinephelus malabracus. Aquaculture Nutrition,13(2), 137-144.

Masiha, A., Soofiani, N.M., Ebrahimi, E., Kadivar, M., \& Karimi, M.R. (2013). Effect of dietary flaxseed oil level on the growth performance and fatty acid composition of fingerlings of rainbow trout, Oncorhynchus mykiss. Springer Plus, 2, 1. https:/ /doi.org/10.1186/2193-1801-2-1.

Mehbood, A., Khan, N., Atiq, U., Iqbal, K.J., Tayyab, R., Batool, S.S., Batool, H.S., Amjad, S., \& Tanveer, M. (2017). Effect of fenugreek as a feed additive on the growth, body composition and apparent nutrients digestibility of striped catfish Pangasius hypophthalmus fry. Pakistan J. Zool., 49, 2037 2042.

Mourente, G., Good, J., \& Bell, J. (2005). Partial substitution of fish oil with rapeseed, linseed and olive oils in diets for European sea bass
(Dicentrarchus labrax L.): Effects on flesh fatty acid composition, plasma prostaglandins $E_{2}$ and $F_{2 a^{\prime}}$ immune function and effectiveness of a fish oil finishing diet. Aquaculture Nutrition, 11, 25-40.

Mu, H., Wei, C., Xu, W., Gao, W., Zhang, W., \& Mai, K. (2020). Effects of replacement of dietary fish oil by rapeseed oil on growth performance, anti-oxidative capacity and inflammatory response in large yellow croaker Larimichthys crocea. Aquaculture Reports, 16, 100251,

Ochang, S.N., Fagbenro, O.A., \& Adebayo, O.T. (2007). Growth performance, body composition, haematology and product quality of the African catfish (Clarias gariepinus) fed diets with palm oil. Pakistan Journal of Nutrition, 6, 452-459.

Picker, M.D. \& Griffiths, C.L. (2011). Alien and invasive animals: A South African perspective. Randomhouse/Struik, Cape Town, South Africa, $224 \mathrm{pp}$.

Piedecausa, M.A., Mazon, M.J., Garcia-Garcia, B., \& Hernandez, M.D. (2007). Effects of total replacement of fish oil by vegetable oil in the diets of sharpsnout sea bream (Diplodus pintazzo). Aquaculture, 263, 211-219.

Richard, N., Kaushik, S., Larroquet, L., Panserat, S., $\&$ Corraze, G. (2006). Replacing dietary fish oil by VOs has little effects on lipogenesis, lipid transport and tissue lipid uptake in rainbow trout (Oncorhynchus mykiss). British Journal of Nutrition, 96, 299-309.

Sargent, J.R., Tocher, D.R., \& Bell, J.G. (2002). The lipids. Fish Nutrition, 3, 181-257.

Sener, E. \& Yildiz, M. (2003). Effect of the different oil on growth performance and body composition of rainbow trout (Oncorhynchus mykiss W., 1792) juveniles. Turkish Journal of Fisheries and Aquatic Sciences, 3, 111-116.

Shiau, S.Y. \& Lin, S.F. (1993). Effect of supplementary dietary chromium and vanadium on the utilization of different carbohydrates in tilapia, Oreochromis niloticus x 0 . aureus. Aquaculture, 110, 321-330.

Toyes-Vargas, E.A., Parrish, C.C., Viana, M.T., CarreónPalau, L., Magallón-Servín, P., \& Magallón-Barajas, F.J. (2020). Replacement of fish oil with camelina (Camelina sativa) oil in diets for juvenile tilapia (var. GIFT Oreochromis niloticus) and its effect on growth, feed utilization and muscle lipid composition. Aquaculture, 735177. doi:10.1016/ j.aquaculture. 2020.735177. 
Turchini, G.M., Mentasti, T., Frøyland, L., Orban, E., Caprino, F., Moretti, V.M., \& Valfre, F. (2003). Effects of alternative dietary lipid sources on performance, tissue chemical composition, mitochondrial fatty acid oxidation capabilities and sensory characteristics in brown trout (Salmotrutta L.).Aquaculture, 225, 251-267.

Wang, A., Han, G., Qi, Z., Lv, F., Yu, Y., Huang, J., Wang, T., \& Xu, P. (2013).Cloning of lipoprotein lipase (LPL) and the effects of dietary lipid levels on LPL expression in GIFT tilapia (Oreochromis niloticus). Aquaculture International, 21, 12191232.

Wassef, E.A., Saleh, N.E., \& El-Abd El-Hady, H.A. (2009). Vegetable oil blend as alternative lipid resource in diets for gilthead seabream, Sparusaurata. Aquaculture International, 17, 421-435.

Yýldýz, M., Eroldoðan, O.T., Engin, K., Gülçubuk, A., $\&$ Baltacý, M.A. (2013). Effects of dietary cottonseed and/or canola oil inclusion on the growth performance, FA composition and organ histology of the juvenile rainbow trout, Oncorhynchus mykiss. Turkish Journal of Fisheries and Aquatic Sciences, 13, 453-464.

Yong, A.S.K., Mubarak, N.S.S., \& Shapawi, R. (2019). Effects of partial replacement of fish oil with different VOs on growth, feed utilization and fatty acid profile of hybrid grouper juvenile (Epinephelus fuscoguttatus x Epinephelus lanceolatus). Journal of Oil Palm Research,31(1), 110-121. 